\title{
EFFECT OF TI AND B ADDITIONS AS POWDER AND PRELIMINARY ALLOY WITH AL-SI ALLOY ON MICROSTRUCTURE AND MECHANICAL PROPERTIES OF ALSI9MG ALLOY INTENDED FOR PARTS OF AGRICULTURAL MACHINERY
}

\author{
Tomasz Lipinski ${ }^{1}$, Dariusz Karpisz ${ }^{2}$ \\ ${ }^{1}$ University of Warmia and Mazury in Olsztyn, Poland; ${ }^{2}$ Cracow University of Technology, Poland \\ tomaszlipinski.tl@gmail.com, dariusz.karpisz@pk.edu.pl
}

\begin{abstract}
Foundry aluminum silicon alloys are widely used in various industries. In their unmodified state, they are not used for construction materials. Their use is possible after improving the unfavourable microstructure. Initially, the microstructure of hypoeutectic silumins is composed of a large primary $\alpha$-phase and large, sharpshaped eutectic silicon grains. This phase creates microstructural notches. This microstructure is the reason for the low mechanical properties of the alloy. Increasing the properties of hypoeutectic silumins can be achieved, inter alia, by introducing chemical additives into the alloy, which refine the microstructure. There are reports in the literature on the use of various chemical compounds and technologies aimed at fragmenting the microstructure. A new approach is the modification process using a homogeneous modifier. This process does not introduce new alloying elements into the alloys. However, this process did not fragment the primary $\alpha$-phase. The paper presents the results of AlSi9Mg alloy modification with AlSi9Mg alloy and boron and titanium. The test results confirm the effectiveness of the applied treatment. After it was carried out, the $\alpha+\beta$ eutectic and the primary $\alpha$ phase were fragmented. These changes, represented by the fragmentation of the microstructure, turned out to be correlated with an increase in the tensile strength of the alloy and its plasticity. The highest mechanical parameters $\left(\mathrm{R}_{\mathrm{m}}=195 \mathrm{MPa}\right.$ and $\left.\mathrm{A}=6.5 \%\right)$ were obtained for the alloy with $0.6 \% \mathrm{Al}-\mathrm{Si}+0.15 \% \mathrm{Ti}+0.06 \% \mathrm{~B}$.
\end{abstract}

Keywords: Al-Si alloy, silumin, modification, mechanical properties.

\section{Introduction}

Casting aluminum-silicon alloys have favourable performance properties, including mechanical and chemical properties with low specific gravity [1-3]. This is the reason why they are widely used in industry $[4 ; 5]$. They also have imperfections on microstructure [6] similar as other foundry alloys [7-9] and mechanical treatment [10]. A big problem is the tendency of silumins to form a coarse-grained microstructure. This microstructure is the reason for the low mechanical properties of the alloys [1-3; 5]. Increasing the properties of alloys can be achieved through an appropriately designed crystallization process [11-13], modification [14-16], through the use of appropriate technological processes: plasma [17], welding [18], homogeneous modifying [19]. For economic reasons the structure [20] and microstructure [21] of alloys are tested and simulation properties of alloys using numerical methods [5].

Modification processes date back to 1920s [22]. Since then, the progress in the processes of increasing the functional properties of silumin has been enormous [23]. It has been proved that the mechanical properties of cast Al-Si alloys depend not only on the chemical composition [24-25], but more importantly on the microstructure itself, in particular the morphology of the $\alpha$ dendritic phase, eutectic $b$ particles and other intermetallic compounds present in the microstructure [26-28]. It was found that the addition of modifiers, initially sodium and strontium, to Al-Si casting alloys significantly improves mechanical properties, especially ductility [29-32]. The influence of strontium on the stability of phase fragmentation and mechanical properties is more noticeable and more durable than that of sodium [32-35]. The improvement in mechanical properties is generally attributed to changes in the morphology and size of the eutectic particles of the silicon phase. It is worth noting, however, that at the same time as eutectic silicon particles change from acicular to fibrous, the amount, morphology, and size of the dendritic $\alpha$-phase also change. The mechanical properties of hypoeutectic silumins are first of all affected by the shape and size of the eutectic mixture $(\alpha+\beta)$. Chemical elements and compounds, both added to the alloy and formed as a result of exothermic reactions [15] or homogenical modifier [19] "pass" into the alloy, changing the course of its crystallization. Selection of the mixture components allows - to a degree - to decide about the starting moment of crystallization and change the range of solidification of alloy or its individual phases. The results of modification of eutectic and hypoeutectic aluminum-silicon alloys by sodium, strontium, antimony and other additions in the metallurgic process have been already analyzed and described by numerous authors [36-39]. 
The aim of the present investigation was to evaluate the influence of the homogenous modifier Al$\mathrm{Si}$ in correlation with boron and titanium on the microstructure, tensile strength and elongation of $\mathrm{AlSi} 9 \mathrm{Mg}$ alloy.

\section{Materials and methods}

The research was carried out on hypoeutectic silumin AlSi9Mg (Table 1). The alloy was obtained from industrial piglets. The alloy was melted in a ceramic crucible made of $\mathrm{Al} 2 \mathrm{O} 3$ in an electric furnace. The alloying elements were introduced into the crucible simultaneously with the liquid melt. The Al-Si addition was produced by cooling the AlSi9Mg alloy at a speed of $200 \mathrm{~K} / \mathrm{s}$, and then mechanically ground into a fraction of $0.18-0.25 \mathrm{~mm}$. The $\mathrm{Ti}+\mathrm{B}$ additions were obtained from the powders. The blends were prepared by mixing the 3 components together using a total factorial experiment $\left(2^{3}\right)$ for three independent variables (Table 2 with mechanical properties of AlSi9Mg alloy at each point in the research plan). The alloy was modified at $1073 \mathrm{~K}$ for 8 minutes (Table 2). Cylindrical samples $8 \mathrm{~mm}$ in diameter and $75 \mathrm{~mm}$ long were poured into dry sand molds. A static tensile test was performed on a specimen with a length to diameter ratio of 5: 1 in the ZD-30 universal tensile tester in accordance with ISO 6892-1: 2019 [40]. The results were analyzed mathematically, which enabled to formulate the factor equation for three variables for the parameters studied, at the level of significance $\alpha=0.05$. The adequacy of the above mathematical equation was verified using the Fischer criterion for $p=0.05$.

Table 1

Real chemical composition of the tested AlSi9Mg, wt.\%

\begin{tabular}{|c|c|c|c|c|c|c|c|c|c|c|}
\hline Element & $\mathbf{S i}$ & $\mathbf{M g}$ & $\mathbf{M n}$ & $\mathbf{N i}$ & $\mathbf{C r}$ & $\mathbf{F e}$ & $\mathbf{C u}$ & $\mathbf{Z n}$ & $\mathbf{T i}$ & $\mathbf{A l}$ \\
\hline Content & 9.24 & 0.34 & $<0.005$ & 0.003 & 0.05 & 0,15 & 0.03 & 0.007 & 0.001 & balance \\
\hline
\end{tabular}

Level of variables and mechanical properties of AISi9Mg alloy

Table 2

\begin{tabular}{|c|c|c|c|c|c|}
\hline $\begin{array}{c}\text { Experiment } \\
\text { points }\end{array}$ & Al-Si, \% & Ti, $\%$ & $\mathbf{B}, \boldsymbol{\%}$ & $\mathbf{R}_{\mathbf{m}}, \mathbf{M P a}$ & $\mathbf{A}, \boldsymbol{\%}$ \\
\hline 1 & 0.2 & 0.05 & 0.02 & 156 & 3.1 \\
\hline 2 & 0.6 & 0.05 & 0.02 & 182 & 5.6 \\
\hline 3 & 0.2 & 0.15 & 0.02 & 178 & 3.8 \\
\hline 4 & 0.6 & 0.15 & 0.02 & 185 & 5.4 \\
\hline 5 & 0.2 & 0.05 & 0.06 & 181 & 4.9 \\
\hline 6 & 0.6 & 0.05 & 0.06 & 191 & 5.8 \\
\hline 7 & 0.2 & 0.15 & 0.06 & 184 & 5.5 \\
\hline 8 & 0.6 & 0.15 & 0.06 & 195 & 6.5 \\
\hline 9 & 0.4 & 0.1 & 0.04 & 187 & 5.2 \\
\hline 10 & 0.4 & 0.1 & 0.04 & 189 & 5.2 \\
\hline 11 & 0.4 & 0.1 & 0.04 & 189 & 5.3 \\
\hline
\end{tabular}

\section{Results and discussion}

The microstructure of the AlSi9Mg alloy with $0.2 \% \mathrm{Al}-\mathrm{Si}+0.05 \% \mathrm{Ti}+0.02 \% \mathrm{~B}$ (Fig. 1) consists of the dendritic $\alpha$ phase against the background of a thick lamellar eutectic $(\alpha+\beta)$. After increasing the share of Ti and B to a higher level, respectively $0.15 \% \mathrm{Ti}$ and $0.06 \% \mathrm{~B}$, the fragmentation of the eutectic was noted $(\alpha+\beta)$. "Breaking" of the dendrites of the primary $\alpha$ phase was also observed. After introducing a mixture of $0.6 \% \mathrm{Al}-\mathrm{Si}+0.05 \% \mathrm{Ti}+0.06 \% \mathrm{~B}$ into the alloy, further disintegration of the eutectic $(\alpha+\beta)$ and clustering of the phase were observed. For the AlSi9Mg alloy with $0.6 \% \mathrm{Al}-$ $\mathrm{Si}+0.15 \% \mathrm{Ti}+0.06 \% \mathrm{~B}$ (all components at the higher level), the disappearance of the thick plates of the eutectic phase $(\alpha+\beta)$ and the fragmentation of the dendritic $\alpha$ phase was noted. The parallel arrangement of the $\beta$-phase eutectic plates observed in the microstructure was considered to confirm the stability of the eutectic formation process $(\alpha+\beta)$. From the comparison of the microstructure, it can be concluded that the greatest fragmentation of the eutectic $(\alpha+\beta)$ and the primary $\alpha$ phase was obtained for this composition. This assumption is confirmed by the mechanical properties of the alloy. 
Figures showing mechanical properties were prepared for the obtained regression equations assuming one of the components at the level of changes: lower or higher. Tensile strength of the $\mathrm{AlSi} \% \mathrm{Mg}$ alloy treated with $\mathrm{Al}-\mathrm{Si}+\mathrm{Ti}+\mathrm{B}$ is shown in Figs. 5, 7, 9, 11, 13 and 15 and elongation in Figures $6,8,10,12,14$ and 16. After treatment of the AlSi9Mg alloy with $0.2 \% \mathrm{Al}-\mathrm{Si}+0.05 \%$ $\mathrm{Ti}+0.02 \% \mathrm{~B}, \mathrm{Rm}=156 \mathrm{MPa}$ and $\mathrm{A}=3.1 \%$ were obtained.

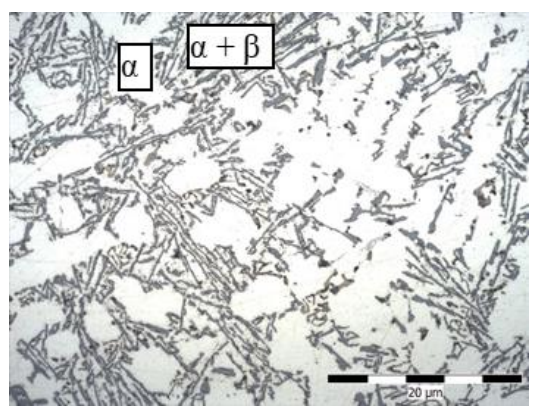

Fig. 1. Microstructure of AISi9Mg alloy with $0.2 \% \mathrm{Al}-\mathrm{Si}+\mathbf{0 . 0 5 \%} \mathrm{Ti}+\mathbf{0 . 0 2 \%} \mathrm{B}$

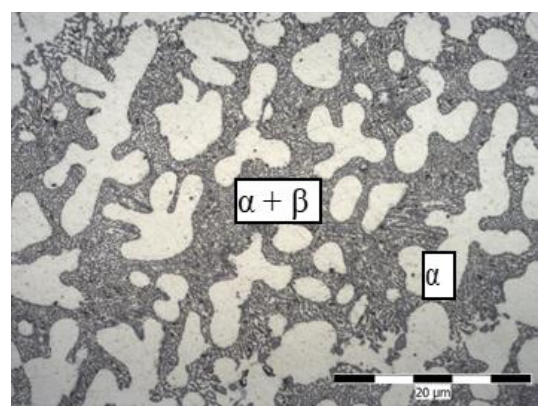

Fig. 3. Microstructure of AISi9Mg alloy with $0.6 \% \mathrm{Al}-\mathrm{Si}+\mathbf{0 . 0 5 \%} \mathrm{Ti}+\mathbf{0 . 0 6 \%} \mathrm{B}$

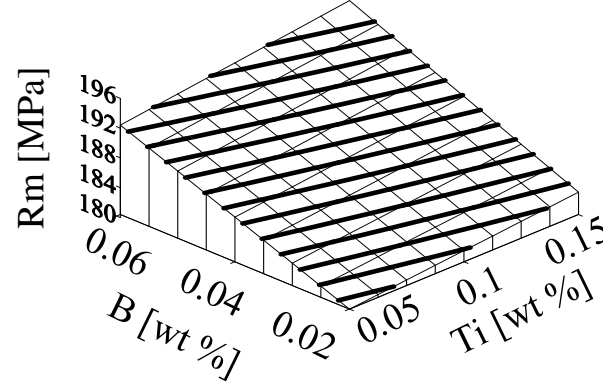

Fig. 5. Tensile strength of AlSi9Mg alloy with $\mathrm{Ti} \in<0.05,0.15>\%$ and $\mathrm{B} \in<0.02$, $0.06>\%$ for $\mathrm{Al}-\mathrm{Si}=\mathbf{0 . 8 \%}$

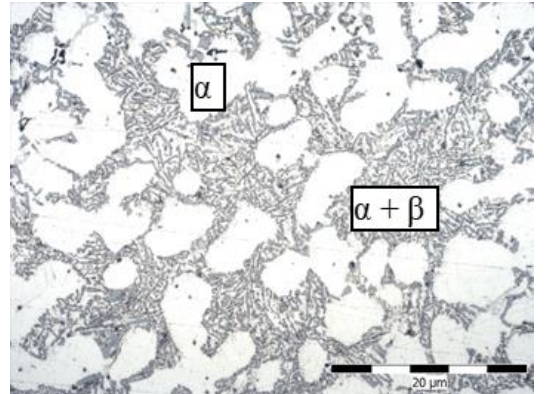

Fig. 2. Microstructure of AlSi9Mg alloy with $0.2 \% \mathrm{Al}-\mathrm{Si}+\mathbf{0 . 1 5 \%} \mathrm{Ti}+\mathbf{0 . 0 6 \%} \mathrm{B}$

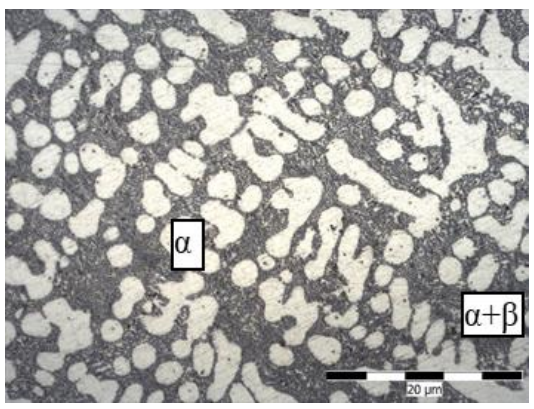

Fig. 4. Microstructure of AISi9Mg alloy with $0.6 \% \mathrm{Al}-\mathrm{Si}+\mathbf{0 . 1 5 \%} \mathrm{Ti}+\mathbf{0 . 0 6 \%} \mathrm{B}$

After increasing the proportion of titanium in the mixture to $0.15 \%$, an increase in the strength to $178 \mathrm{MPa}$ and elongation to $3.8 \%$ were noted. After introducing boron at a level higher than $0.06 \%$, a further increase in the strength to $184 \mathrm{MPa}$ and elongation to 5.5\% were noted. After changing the Al$\mathrm{Si}$ additions to a higher level, $\mathrm{Rm}=195 \mathrm{MPa}$ and $\mathrm{A}=6.5 \%$ were obtained. At this point in the research agenda, all three add-ons are at a higher level.

The analyzed mechanical parameters for this point of the research plan obtained the highest values. After treatment of the AlSi9Mg alloy with $0.6 \% \mathrm{Al}-\mathrm{Si}+0.05 \% \mathrm{Ti}+0.02 \% \mathrm{~B}, \mathrm{Rm}=182 \mathrm{MPa}$ and $\mathrm{A}=5.6 \%$ were obtained, and after increasing the amount of titanium to $0.15 \%, \mathrm{Rm}=185 \mathrm{MPa}$ and $\mathrm{A}=5.4 \%$ were obtained. After treatment of the AlSi9Mg alloy with $0.2 \% \mathrm{Al}-\mathrm{Si}+0.05 \% \mathrm{Ti}+0.06 \% \mathrm{~B}$, $\mathrm{Rm}=181 \mathrm{MPa}$ and $\mathrm{A}=4.9 \%$ were obtained. Based on the analysis of the test results (Figures 5-15), it was found that the Al-Si component, and then $\mathrm{B}$, had the highest effectiveness of the impact on the strength and at the same time elongation of the alloy. Titanium interacted with the lowest intensity. 


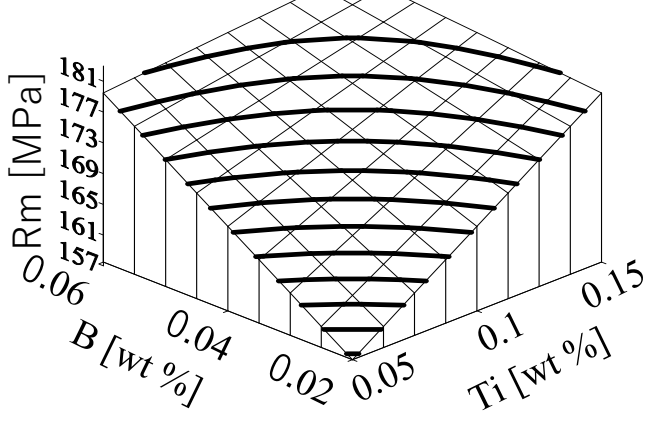

Fig. 7. Tensile strength of AISi9Mg alloy with $\mathrm{Ti} \in<0.05,0.15>\%$ and $\mathrm{B} \in<0.02$, $0.06>\%$ for $\mathrm{Al}-\mathrm{Si}=0.4 \%$

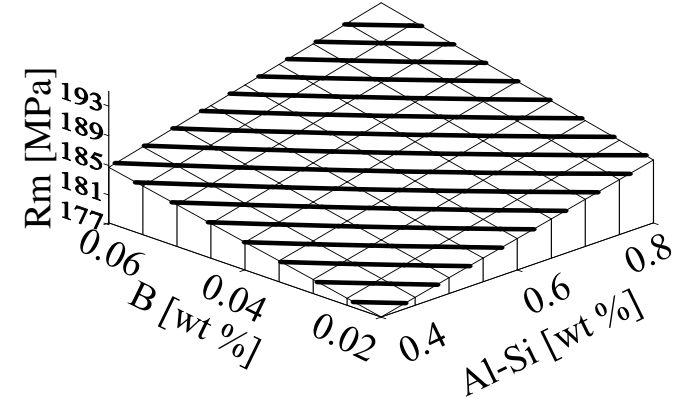

Fig. 9. Tensile strength of AISi9Mg alloy with Al-Si $\in<0.4,0.15>\%$ and $B \in<0.02$, $0.06>\%$ for $\mathrm{Ti}=\mathbf{0 . 1 5 \%}$

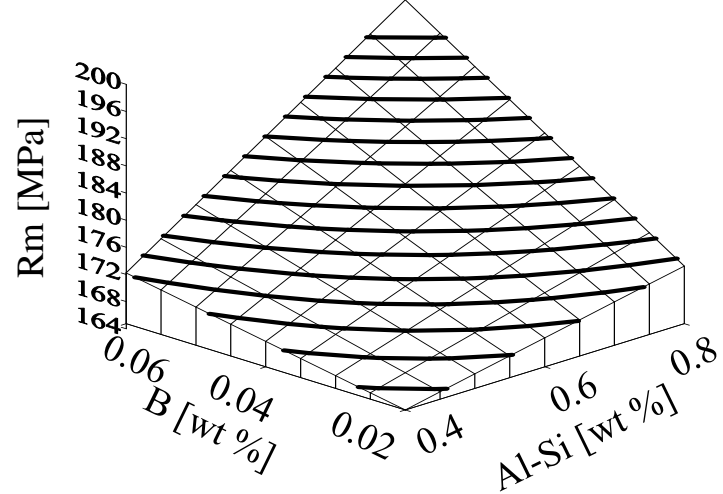

Fig. 11. Tensile strength of AISi9Mg alloy with Al-Si $\in<0.4,0.15>\%$ and $B \in<0.02$, $0.06>\%$ for $\mathrm{Ti}=0.05 \%$

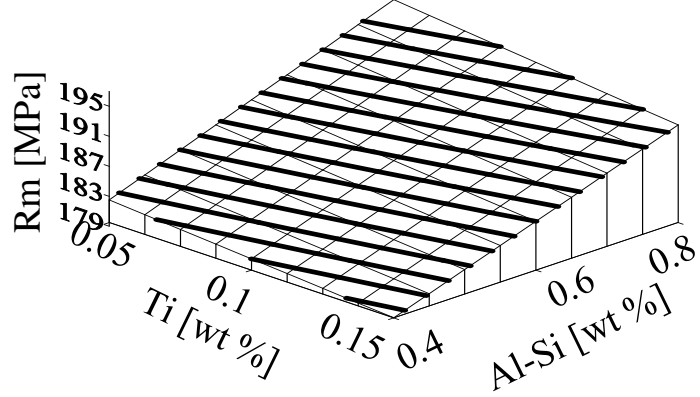

Fig. 13. Tensile strength of AISi9Mg alloy with Al-Si $\in<0.4,0.15>\%$ and

$\mathrm{Ti} \in<0.05,0.15>\%$ for $\mathrm{B}=0.06 \%$

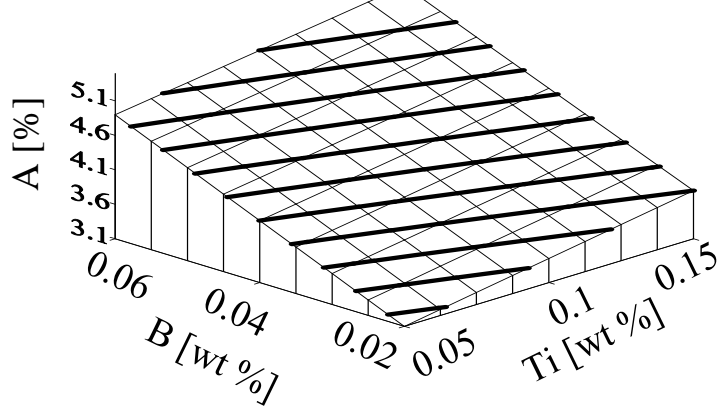

Fig. 8. Elongation of AlSi9Mg alloy with Ti $\in<0.05,0.15>\%$ and $B \in<0.02$, $0.06>\%$ for $\mathrm{Al}-\mathrm{Si}=0.4 \%$

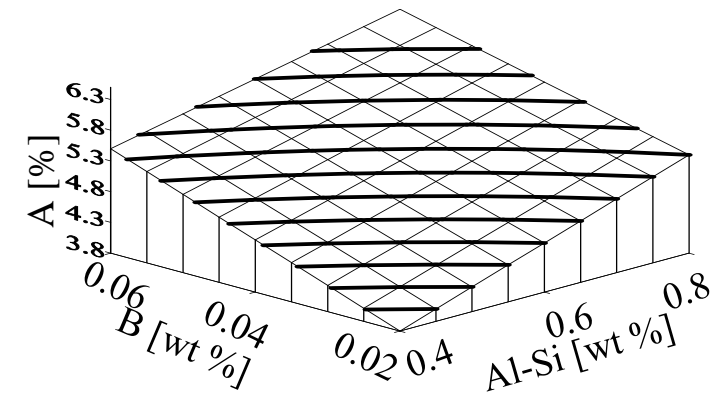

Fig. 10. Elongation of AlSi9Mg alloy with $\mathrm{Al}-\mathrm{Si} \in<0.4,0.15>\%$ and $\mathrm{B} \in<0.02$, $0.06>\%$ for $\mathrm{Ti}=0.15 \%$

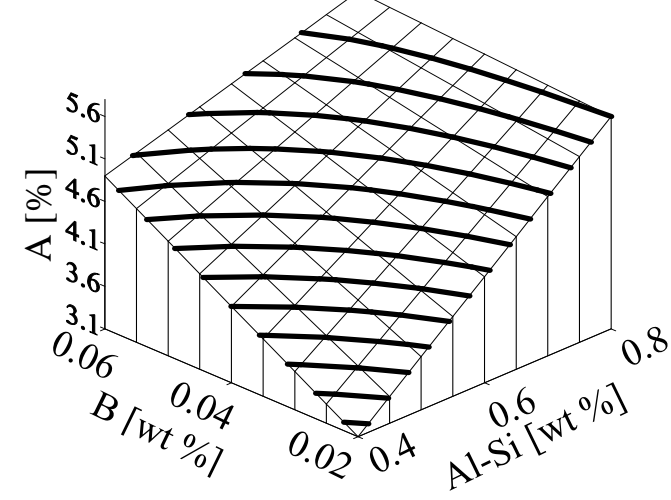

Fig. 12. Elongation of AlSi9Mg alloy with Al$\mathrm{Si} \in<\mathbf{0 . 4 , 0 . 1 5}>\%$ and $\mathrm{B} \in<0.02$, $0.06>\%$ for $\mathrm{Ti}=\mathbf{0 . 0 5 \%}$

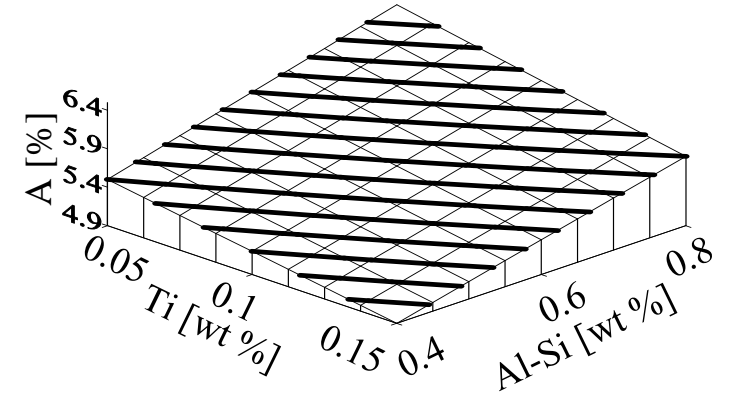

Fig. 14. Elongation of AlSi9Mg alloy with $\mathrm{Al}-\mathrm{Si} \in<0.4,0.15>\%$ and $\mathrm{Ti} \in<0.05$, $0.15>\%$ for $B=0.06 \%$ 


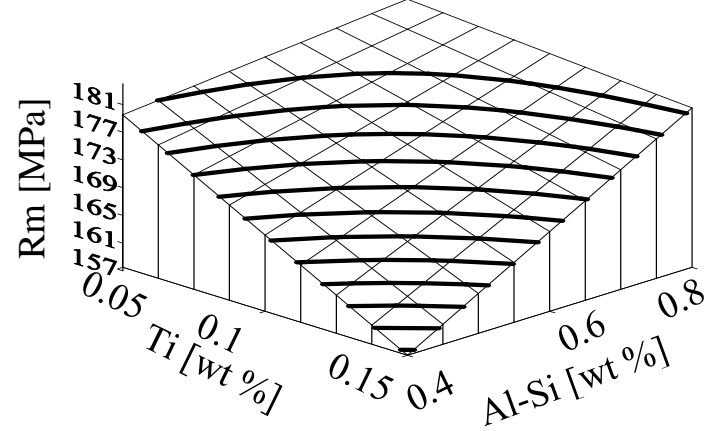

Fig. 15. Tensile strength of AlSi9Mg alloy with Al-Si $\in<0.4,0.15>\%$ and $\mathrm{Ti} \in<0.05,0.15>\%$ for $\mathrm{B}=\mathbf{0 . 0 2 \%}$

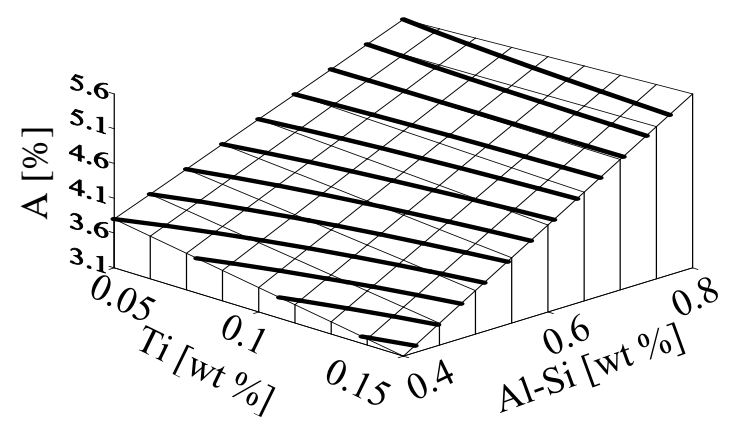

Fig. 16. Elongation of AlSi9Mg alloy with $\mathrm{Al}-\mathrm{Si} \in<\mathbf{0 . 4 , 0 . 1 5}>\%$ and $\mathrm{Ti} \in<0.05$, $0.15>\%$ for $B=0.02 \%$

\section{Conclusions}

1. The microstructure obtained at all points of the research plan is characterized by a lamellar structure with a different degree of development of the $\alpha$ phase and $(\alpha+\beta)$ eutectic.

2. The analyzed blend components rapidly cooled $\mathrm{Al}-\mathrm{Si}$, Ti and $\mathrm{B}$ used for the treatment of the AlSi9Mg silumin showed a significant effect on the tensile strength and elongation. The effectiveness of the interaction of both $\mathrm{T}$ and $\mathrm{B}$ increases with the increase in the share of Al-Si in the mixture.

3. The highest mechanical parameters $(\mathrm{Rm}=195 \mathrm{MPa}$ and $\mathrm{A}=6.5 \%)$ were obtained for the alloy with $0.6 \% \mathrm{Al}-\mathrm{Si}+0.15 \% \mathrm{Ti}+0.06 \% \mathrm{~B}$.

\section{References}

[1] Michna S., Lukac I., Ocenasek V., Koreny R., Drapala J., Schneider H., Miskufova A. Encyclopaedia of aluminium. Adin s.r.o. Presov. 2005 (In Czech).

[2] Martinovsky M., Madl J. The effect of different modifiers on cutting temperature in turning of AlSi7Mg0.3 alloy. Manufacturing Technology, Vol. 18, No. 6, 2018, pp. 950-953.

[3] Flemings MC. Solidification processing. Metallurgical and Material Tran. B 5, 1974, pp. 2121-34.

[4] Selejdak J., Ulewicz R., Ingaldi M. The evaluation of the use of a device for producing metal elements applied in civil engineering. 23rd International Conference on Metallurgy and Materials. Bron Czech Republic 21-23.05.2014, pp. 1882-1888.

[5] Szczotok A., Gądek-Moszczak A., Pietraszek J., Radek N., Dwornicka R. Simulation-based engineering science Challenges of the 21st Century Applied Mechanics and Materials Volume 712 Trans Tech Publ. 2015, pp. 3-8.

[6] Mondolfo LF. Aluminum alloys: structure and properties. London: Butterworths 1978.

[7] Ulewicz R., Selejdak J. et al. Process management in the cast iron foundry. 22nd International Conference on Metallurgy and Materials. Bron Czech Republic 15-17.05.2013, pp.1926-1931.

[8] Vitalii B., Dudek A. Evaluation of composite epoxy resin applicability for concrete coatings. Composites Theory and Practice 17(4), 2017, pp. 221-225.

[9] Dudek A., Lisiecka B., The effect of thermal oxidation of porous and non-porous titanium alloy. 26td International Conference on Metallurgy and Materials. Bron Czech Republic 2017, pp. 1234.

[10] Novak M., Naprstkova N., Ruzicka L. New ways in aluminium alloys grinding. In: Key Engineerings Materials, Vol. 496, 2012, pp. 132 - 137.: Precision Machining IV. TTP. Zurich.

[11] Kurz W., Fisher D. J. Fundamentals of Solidifications. TTP. Switzerland 1986.

[12] Elliott R. Eutectic Solidification Processing, Butterworts, London 1983.

[13] Yaparova N.M. Method for determining particle growth dynamics in a two-component alloy. Izvestiya. Ferrous Metallurgy Vol. 63(2), 2020, pp. 135-139. (In Russ.)

[14] Nova I., Frana K., Sobotka I., Solfronk P., Korecek D., Novakova I. Production of porous aluminium using sodium chloride. Manufacturing Technology 19(5), 2019, pp. 817-822.

[15] Lipiński T., Analysis of Mechanical Properties of AlASi9Mg Alloy with Al, Ti and B Additions. Manufacturing Technology 17(5), 2017, pp. 761-766. 
[16] Lipiński T., Bramowicz M., Szabracki P., The Microstructure and Mechanical Properties of Al7\% SiMg Alloy Treated with an Exothermic Modifier Containing Na and B. Solid State Phenomena 203-204, 2013, pp. 250-253.

[17]Zaguliaev, D., Konovalov, S., Ivanov, Y., Gromov, V. Effect of electron-plasma alloying on structure and mechanical properties of Al-Si alloy. Applied Surface Science, Vol. 498, 2019, 143767 (online).

[18] Lipiński T., Influence of Surface Refinement on Microstructure of Al-Si Cast Alloys Processed by Welding Method. Manufacturing Technology 15(4), 2015, pp. 576-581.

[19]Lipiński T., The structure and mechanical properties of Al-7\%SiMg alloy treated with a homogeneous modifier. Solid State Phenomena Vol. 163 (2010) pp. 183-186.

[20] Gądek-Moszczak A., Pietraszek J., Jasiewicz B., Sikorska S., Wojnar L. The bootstrap approach to the comparison of two methods applied to the evaluation of the growth index in the analysis of the digital X-ray image of a bone regenerate. Studies in Computational Intelligence 572, 2015, pp. 127 136.

[21] Gadek-Moszczak A.: History of stereology. Image Analysis and Stereology 36(3), 2017, pp. 151-

[22] Pacz A. Alloy. US Patent, 1921, No. GB158827.

[23] Theile W., Dunkel E. On the Long-Term Modification of Aluminum-Silicon Alloys. Giesserei, Vol. 23, 1966, pp.768.

[24] Kraus P., Náprstková N., Jirounková K., Cais J., Svobodová J. Effect of heat treatment on the microstructure of the alloy AlSi7CrMnCu2.5. Manufacturing Technology, Vol. 18, No. 6, 2018, pp. 935-942.

[25] Bolibriichová D., Hajdúch P., Brůna M. Influence of molybdenum, zircon and copper on structure of aluminum alloy $\operatorname{AlSil0Mg}(\mathrm{Cu})$ (En Ac-43200). Manufacturing Technology, Vol. 18, No. 5, 2018, pp. 709-718.

[26] Konovalov S. V., Zagulyaev D. V., Ivanov Y. F., Gromov V. E. Effect of yttrium oxide modification of Al-Si alloy on microhardness and microstructure of surface layers. Metalurgija, Vol. 57, No. 4, 2018, pp. 253-256.

[27] Lipinski T. Influence of Ti and melt number on microstructure and mechanical properties of $\mathrm{Al}-\mathrm{Si}$ alloy on agriculture machine parts. In: Proceedings of Engineering for Rural Development, Vol. 17, 2018, pp. 1431-1436. Jelgava, Latvia.

[28] Troeger L., Starke Jr E. Microstructural and mechanical characterization of a superplastic 6xxx aluminum alloy. Material Science and Engineering A 277, 2000, pp. 102-113.

[29] Hren I., Svobodova J. Fractographic analysis of strontium-modified al-si alloys. Manufacturing Technology, Vol. 18, No. 6, 2018, pp. 900-905.

[30] Lipiński T. Effect of $\mathrm{Sr}$, Ti and $\mathrm{B}$ additions as powder and a preliminary alloy with $\mathrm{Al}$ on microstructure and tensile strength AlSi9Mg alloy. Manufacturing Technology Vol. 19 No 5, 2019, pp. 807-812.

[31]Lipinski T. Effect of combinative cooled addition of strontium and aluminium on mechanical properties AlSi12 alloy. Journal of Achievements in Materials and Manufacturing Engineering, 83 (1), 2017, pp. 5-11.

[32] Lipiński T., Szabracki P. Mechanical Properties of AlSi9Mg Alloy with a Sodium Modifier. Solid State Phenomena Vol. 223, 2015, pp. 78-86.

[33] Chikova O. A, Nikitin K. V., Moskovskikh O. P., Tsepelev V. S. Viscosity end electrical conductivity of liquid hypereutectic alloys Al-Si. In: Acta Metallurgica Slovaca, Vol. 22, No. 3, 2016, pp. 153-163.

[34] Wołczyński W., Guzik E., Wajda W., Jedrzejczyk D., Kania B., Kostrzewa M. Cet in solidifying roll - thermal gradient field analysis. Archives of Metallurgy and Materials, Vol. 57, No. 1, 2012, pp. 105-117.

[35] Bolibruchová D., Matějka M., Kúriš M. Analysis of the impact of the change of primary and secondary AlSi9Cu3 alloy ratio in the batch on its performance. Manufacturing Technology 19(5), 2019, pp. 734-739.

[36] Naprstkova N., Kraus P., Stancekova D. Calcium and its using for modification of AlSi7Mg0.3 alloy from view of final microstructure and hardness. Proceedings of Engineering for Rural Development, Vol. 17, 2018, pp. 2003-2008. Jelgava, Latvia. 
[37] Hren I., Svobodova J., Michna S. Analysis of Microstructure Changes for AlSi7Mg0.3 Alloy Caused by Modification. Manufacturing Technology 19(5), 2019, pp. 767-771.

[38] Lipiński T. Modification of Al-11\% Si alloy with Cl - based modifier. Manufacturing Technology Vol. 15, No. 4, 2015, pp. 581-587.

[39] Liu XF, Wu YY, Bian XF. The nucleation sites of primary Si in Al-Si alloys after addition of boron and phosphorus. Journal of Alloys and Compounds 391, 2005, pp. 90-94.

[40] ISO 6892-1:2019. Metallic materials - Tensile testing — Part 1: Method of test at room temperature. 